\title{
Impact Testing Method of Sock Slipping for Soccer Sports
}

\author{
WAKako Lina $^{\text {a }}$, Yatsuka Masato ${ }^{\text {b }}$, SAItoh Saki ${ }^{\text {b }}$, Kanai Hiroyuki ${ }^{\text {b, * }}$ \\ ${ }^{a}$ Institute of Science and Engineering, Kanazawa University, Kakuma-machi, Kanazawa 920-1192, Japan \\ ${ }^{\mathrm{b}}$ Faculty of Textile Science and Technology, Shinshu University, 3-15-1 Tokida, Ueda, Nagano 386-8567, Japan
}

Received 2 December 2014; accepted for publication 26 June 2015

\begin{abstract}
In order to design new socks for soccer sports that do not slip down easily, we performed impact tests by jumping down of a subject wearing socks, so as to analyze and understand the principals involved in sock slipping. We then developed a prototype impact testing device of sock slipping and performed several impact tests.

Impact sock slipping can be explained by a simple dynamical model of three forces generated by the collision between the sock-covered leg and the ground. The three forces are the inertial force acting on the sock, frictional force acting between the sock and leg, and impulsive force acting on the leg. In the prototype impact testing device, a conical leg model with a sock was allowed to fall freely. The collision between the leg model and the ground was used to evaluate and test the sock slipping. As a result, the impact testing device had excellent reproducibility, and its usefulness was confirmed. To prevent the discomfort due to the sock slipping and ensure the leg safety for soccer sports subjected to severe conditions, novel socks designs of soccer sports will be needed to control the material, stitch, clothing pressure, and coefficient of friction according to the end-use performance.
\end{abstract}

Key Words : Soccer sports, Sock slipping, Impact testing device, Dynamical model

\author{
サッカー用スポーツソックスの衝撃ずり落ち試験法

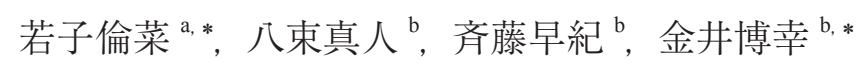 \\ ${ }^{a}$ 金沢大学理工研究域, ${ }^{b}$ 信州大学繊維学部
}

\section{1. 緒 言}

ソックスは，脚部，足部を覆うニット製の被服・繊維製品 であり，丈長さがふくらはぎまでの靴下のことである [1]. また, ソックスは, 丈長さの違いによってアンクレット, ソッ クス, ハイソックスに細分類される。ささらに, カジュアルウェ ア着用時や運動時などの使用用途に応じてカジュアルソック スやスポーツソックスなどのように分類されることもある [1].

一般にソックスには足の保護, 保温, 装飾などの役割があ り，現代の衣料生活においては欠かすことのできない纎維製 品であるため, これまでにも, カジュアルソックスや紳士用 ソックスを対象とした着装時の性能評価や快適性評価に関す る研究が数多くなされている [2-7]. 特に, 軽運動中に着装 当初の状態からソックスが下方向に滑り落ちる, いわゆる「ず
り落ち現象」は, ソックスの基本的な役割や着装時の快適性 を損なう重要な問題であるため多角的な検討がなされてき た [5-7]. 辻坂らの報告によれば, 軽運動時に生じる足首の 屈伸動作によって, 靴とソックスとの間に摩擦が生じ, この 摩擦力によってソックスレッグ部が徐々に引張り下げられる ことでずり落ち現象が生じること, また, 一定のずり落ち量 に達したソックスレッグ部では, ソックスを引張り下げる力 が極端に減少するため, それ以降はずり落ち量が増大しない ことを明らかにしている。これらの知見はいずれも日常生活 における軽運動時のずり落ち現象を詳細に検討したものであ る.

一方，スポーツソックスにおけるずり落ち現象は，足首の 屈伸動作によるずり落ちに加え, 跳躍一接地によって発生す る衝撃に起因するずり落ちや発汗などによる布の吸水がずり 落ちを助長するなどの点でカジュアルソックスの問題とは全

* 連絡先：信州大繊維学部先進繊維工学課程 386-8567 上田市常田 3-15-1 E-mail : kanai@shinshu-u.ac.jp, Tel : +81-268-21-5614 
く異なっている。例えばサッカーは, 求められる運動量が大 きく, 雨天でも決行される激しいスポーツである。競技者は, ボールを蹴り，時には頭でボールを飛ばすだけでなく, プレー 中の接触やスライディング, ジャンプなどを繰り返すために, 脚部の安全性を確保する観点から, スポーツソックスの着用 が義務付けられている。 また，ずり落ち現象によるソックス の弛みが足首部付近に生じることで, 足首の屈伸動作の妨げ となり，競技者の運動性能にも悪影響を及ぼすことになる. このようにスポーツに従事する人にとって，スポーツソック スのずり落ち現象は重要な問題であるにも関わらず, ずり落 ち現象の発生要因の特定や発生メカニズムの解明を目的とし た研究はみられない。 また，スポーツソックスの防ずり落ち 性試験法などの客観的な評価方法が存在しないのが現状であ る.

そこで，スポーツソックスを対象としたずり落ち現象を再 現することができ，かつ，既存のスポーツソックスの防ずり 落ち性について評価できる試験法を提案することを最終目標 として, 本研究では, まず, スポーツ中のソックスのずり落 ち現象の中でも, 跳躍一接地動作によって発生する衝撃が原 因となるずり落ち現象に限定して，（1）ずり落ち現象発生の メカニズムを考察できる簡単な力学モデルを得ること, なら びに，(2) 衝撃に起因するスポーツソックスのずり落ち現象 を再現できる簡易な試験機を試作・活用することで, 先の力 学モデルと試作試験機によるずり落ち現象との一致性を検証 することを目的とした。

\section{2. 衝撃ずり落ち現象の力学モデル}

Fig. 1 は, ソックスが初期位置から滑り移動した距離をず り落ち量 Sとして, ソックス着装脚部が $H_{L}$ の高さから鉛直

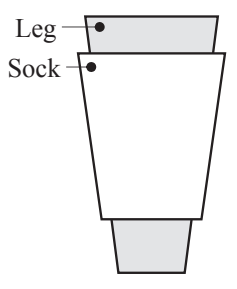

Sock-covered leg

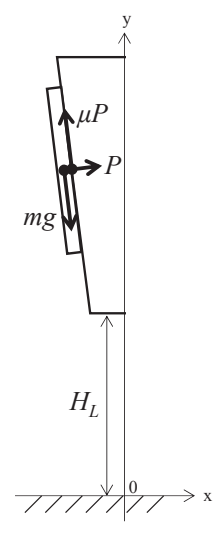

Before dropping

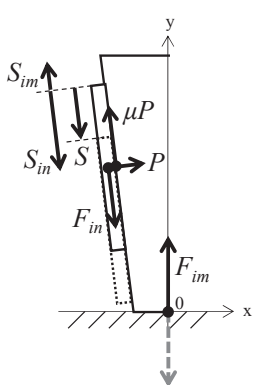

After dropping
(Side view)

(Cross-sectional view)

Fig. 1 Dynamical model of forces acting on sock-covered leg. (m : mass, $\mathrm{g}$ : gravitational acceleration, $\mathrm{P}$ : clothing pressure, $\mu$ : coefficient of friction, $\mathrm{S}:$ impact slippage, $\mathrm{F}:$ force)
自由落下し, 地面に衝突するときに作用する力の概要図であ る。脚部は膝部から足首部にかけて周囲長が減少するために, 脚部上のソックスは $\mathrm{x}$ 軸に対して傾斜することになる。しか しながら，20歳代の標準的な脚部寸法を考慮すると，その 傾斜角度は約 $3.8 \mathrm{deg}$ と非常に微小であることから, 本モデル では無視できるものと仮定する。ソックス着装脚部が地面に 衝突するとき, ソックスには鉛直下向きの慣性力 $F_{i n}$ が作用 し, ソックスと脚部との間の摩擦力 $\mu P$ は脚部に沿って上向 きに作用する、また，脚部には衝突の反作用による鉛直上向 きの衝撃力 $F_{i m}$ が作用する。ここで, ずり落ち量は慣性力お よび抵抗力から生じるずり落ち成分 $S_{i n}$ と衝撃力から生じる ずり落ち成分 $S_{i m}$ から成るものと仮定すると, $S=S_{i n}-S_{i m}$ で表 せる。ついで，ずり落ち成分 $S_{i n}$ は(1)脚部の質量を $M$ とする と, ソックス着装脚部が $H_{L}$ の高さから自由落下して地面に 達した瞬間のソックスの速度 $V\left(H_{L}\right)$ は, エネルギ保存の法則 から $V\left(H_{L}\right)=\sqrt{2 g H_{L}}$, (2)またソックスの運動エネルギ $E_{S}$ は $E_{S}$ $=m V\left(H_{L}\right)^{2} / 2=m g H_{L}$ となる. ソックスの運動エネルギが全て ずり落ち成分に変換されるものとするとき, 摩擦力による仕 事量は運動エネルギ $E_{S}$ と等しいことから, $S_{i n}=m g H_{L} / \mu P$ を 得ることができる.さらに, ずり落ち成分 $S_{i m}$ は(1)脚部が衝 突によって地面から衝撃力 $F_{i m}$ を微小時間 $\Delta t$ だけ受けると, その運動量 $M V\left(H_{L}\right)$ はゼロになるので, 衝撃の前後での運動 量の変化は衝撃力の力積に等しいことから, $M V\left(H_{L}\right)=F_{i m} \Delta t$, (2)また脚部に働く衝撃力は $F_{i m}=M \sqrt{2 g H_{L}} / \Delta t$ である. 衝撃力 は脚部の鉛直上向きへの運動であるはね返りと関係してお り, この鉛直上向きへの運動とソックスとの相対的な作用に よってずり落ち成分 $S_{i m}$ は生じると考えることができる，こ こでは簡単のために最も単純な関係, すなわち衝撃力の大き さに比例してずり落ち成分が増加するものと仮定すると， $S_{i m}$ $=\alpha F_{i m}=\alpha M \sqrt{2 g H_{L}} / \Delta t$ (ただし， $\alpha$ は比例定数）を得る.した がって, ずり落ち量は $S=m g H_{L} / \mu P-\alpha M \sqrt{2 g H_{L}} / \Delta t$ という簡 単な力学モデルから解析できる.

このソックス着装脚部と地面との衝突時の衝撃によって生 じるずり落ちを,ここでは「衝撃ずり落ち」と表現する。また, 落下高さの増加が僅かな小さい範囲においては衝撃ずり落ち 量を二次関数的に増加させ, さらなる増加によっては衝撃ず り落ち量をおよそ比例して増加させるものと解釈できる。 ま た，衝撃力によって脚部が鉛直上向きに運動した場合には， 鉛直上向きの運動に由来するソックスの滑り移動が生じるこ とになるので, この成分を除外するためには試作試験装置に おける脚部質量の検討も必要となる.

なお,ソックスの質量 $m$ は纎維素材や編組織などによって 変化でき, 衣服圧や摩擦係数もソックスの設計内容によって 調整できることから, 衝撃ずり落ちを改善するための重要な 手段になるものと推測できる.

\section{3. 衝撃ずり落ち試験法}

\section{1 試験装置の設計と開発}

Fig. 2 は試作した脚部モデルと衝撃ずり落ち試験装置につ 


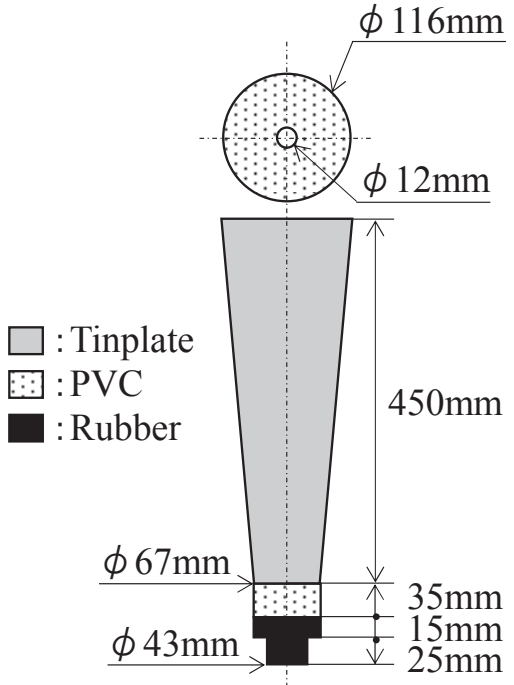

(a) Leg model

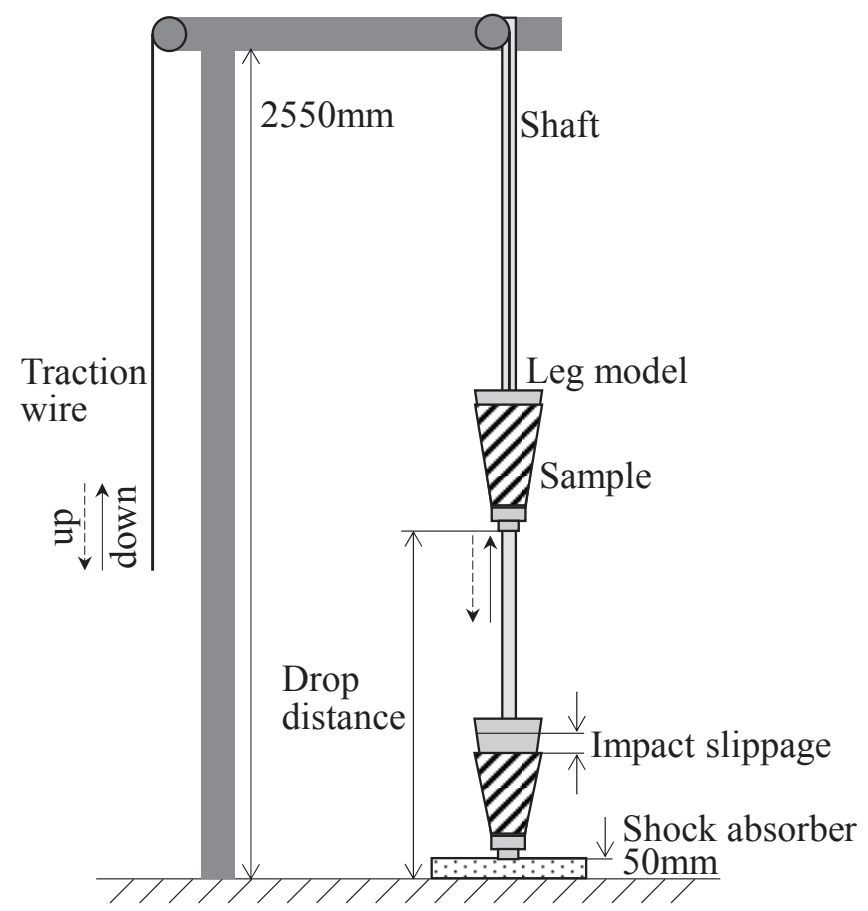

(b) Impact testing device for sock slipping

Fig. 2 Schematic illustrations of leg model and impact testing device for sock slipping.

いて示す。ヒト脚部は膝部から足首部にかけて周囲長が減 少する形状をしていることから，脚部を円錐体で近似した。 Fig. 2(a) は脚部モデルの詳細である. 円錐体には，20～ 30 歳代の標準的な日本人成人における膝部から下腿最小囲部ま での寸法を用いた [8]。この円錐体はブリキ，塩化ビニルの 円盤およびゴムの円盤で構成されている，脚部モデルの重量 は，円錐体内に重りを設置する方法で調整した。Fig. 2(b) は 試作した試験装置の詳細である。脚部モデルには試料ソック スを着装させた状態で, 鉛直方向に自由落下させて地面に衝
Table 1 Sample socks.

\begin{tabular}{lrrr}
\hline Sample & S1 & S2 & S3 \\
\hline Size of length [mm] & & & \\
A & 352 & 365 & 363 \\
B & 114 & 110 & 82 \\
C & 105 & 105 & 90 \\
D & 95 & 75 & 73 \\
Weight [gf] & 30 & 30 & 30 \\
Clothing Pressure [kPa] & 7 & 16 & 19 \\
\hline
\end{tabular}

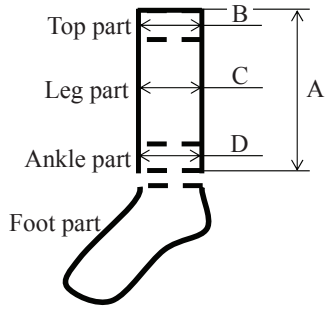

突させる方法である。主要部は，逆 $\mathrm{L}$ 字型の支持台，脚部モ デル, シャフト, 率引ワイヤで構成されている。シャフトは, 脚部モデルを鉛直に落下させるためのガイド丸棒である。牽 引ワイヤを下方に引っ張ると脚部モデルが上方に引き上げら れる，設定した落下高さまで引き上げた後，牽引ワイヤを手 放すことによって脚部モデルを自由落下できる.

\section{2 試験法の検討}

Table 1 は試料ソックスの詳細である。試料 S3 は未使用の ソックスである。試料 S2 は試料 S3 をサッカー競技で使用し た後のソックスであり, 現実的な使用によるソックスの繰返 伸張が行われたものである。また試料 S1 は，試料 S3 を脚部 直径よりも大きい直径をもつ円錐体に 24 時間着装させるこ とによってコース方向に伸長させたソックスである。

試験には試料 S2 を用いることとした。ソックスフット部 を除外して， $20 \pm 2^{\circ} \mathrm{C} ， 65 \pm 5 \%$ R.H. の標準環境下で 24 時間 以上調整し使用した。試料ソックスを脚部に着装する際には, ソックスロゴム部の上端と膝部位, ならびにソックスレッグ 部の下端と下腿最小囲部位とがそれぞれに一致するように注 意した。試験の繰り返しによるソックスの状態変化を最小限 とするため, 測定回数は, 落下回数 1 回を 1 試験とする 1 試 験のみとした。衝撃ずり落ち試験は $20 \pm 2^{\circ} \mathrm{C}, 65 \pm 5 \%$ R.H.の 環境にある室内で実施した。落下高さは, 衝突が最も激しい 運動動作の一つと考えられるサッカープレイ中のジャンプ動

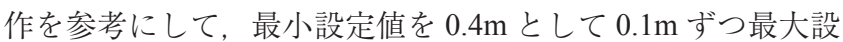
定值を $1.2 \mathrm{~m}$ まで増加させた 9 条件, または最大設定值を $1.5 \mathrm{~m}$ まで増加させた 12 条件のいずれかを採用した。脚部モデル

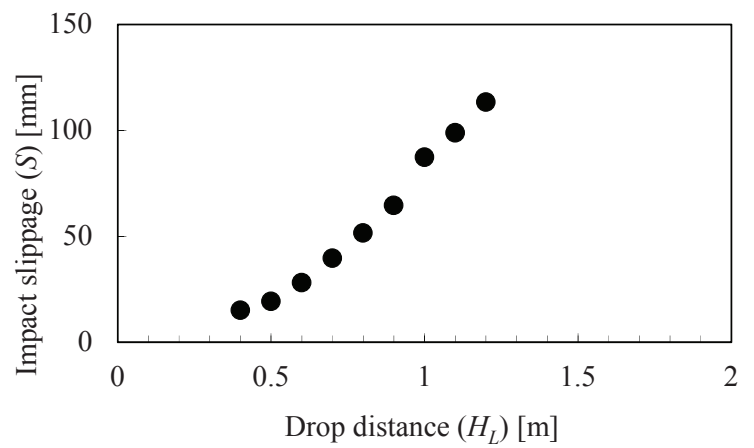

Fig. 3 Relationship between impact slippage and drop distance. 


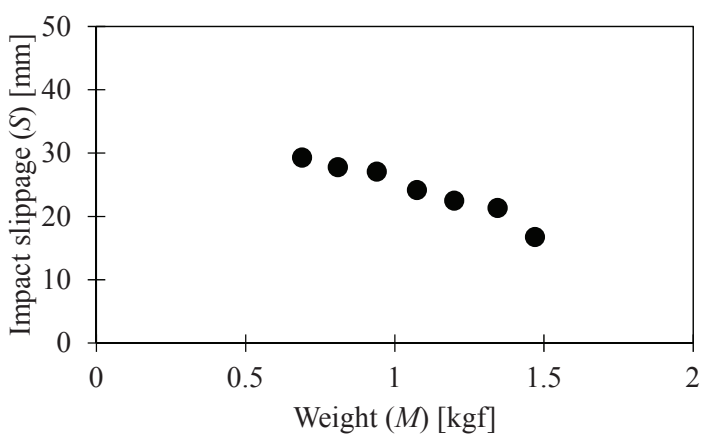

Fig. 4 Relationship between impact slippage and weight of leg model.

重量は, 脚部モデルの材質や重量などがヒト脚部とは全く異 なり衝撃ずり落ち現象への影響の大きさが不明であることか ら, 脚部モデルそのものの重量を利用して 0.7，0.8，0.9，1.1， $1.2,1.3$ および $1.5 \mathrm{kgf} の$ 合計 7 条件を設定した。 また, 脚部 モデルへの衝撃力の作用を制卸する手段の一つとして, 脚部 モデルの落下地点に厚さ $50 \mathrm{~mm}$ の低反発ポリウレタン製衝撃 吸収体を用いることも検討した。

Fig. 3 は, 脚部モデル重量を $0.7 \mathrm{kgf} に$ 限定して一定とした ときの脚部モデル落下高さ（高さ条件 $=9$ 条件）と衝撃ずり 落ち量との関係を示す．落下高さが $0.4 \sim 0.6 \mathrm{~m}$ の小さい範 囲において衝撃ずり落ち量は二次関数的に増加し, 落下高さ がさらに増加すると比例して増加した。この傾向は, 衝撃ず り落ち現象の力学モデルと一致していた。 すなわち, 衝撃力 から生じるずり落ち成分は落下高さの平方根関数で増加し, 慣性力および抵抗力から生じるずり落ち成分は一次関数で増 加するために，その差分である衝撃ずり落ち量は，落下高さ が僅かな小さい範囲においては二次関数的に, さらに落下高 さが増加するとほぼ比例して増加したものと考える。ささら 脚部モデルの重量が増加した場合には, 衝撃力から生じるず り落ち成分が比例して増加すると考えられるので，衝撃ずり 落ち量は落下高さに対する変化傾向が同一でありながらも, 脚部モデル重量に比例して全体的に減少するものと推測でき る.

そこで，落下高さを $0.5 \mathrm{~m}$ に限定して一定としたときの脚 部モデル重量と衝撃ずり落ち量との関係について検討した結
果を Fig. 4 に示す. 脚部モデル重量が増加するとき, 衝撃ず り落ち量も比例して減少した。この傾向は, 衝撃ずり落ち現 象の力学モデルと一致しており, 脚部モデル重量は衝撃力か ら生じるずり落ち成分に比例して影響を及ぼすことがわかっ た。したがって, 解析した力学モデルは非常に簡略化したモ デルではあるが, ソックスの衝撃ずり落ち現象の説明におい て有効である。

落下高さおよび脚部モデル重量と衝撃ずり落ち量との関係 をふまえて, 衝撃力から生じるずり落ち成分を除外する方法 についても検討した。 まず, 落下高さに注目して衝撃吸収体 の影響を検討するために, 脚部モデル重量を衝撃力から生じ るずり落ち成分への影響が最も小さい最軽量の $0.7 \mathrm{kgf}$ で一定 として, 衝撃吸収体を設置した場合と設置しない場合とに分 けて, 脚部モデル落下高さ（高さ条件 $=9$ 条件）と衝撃ずり 落ち量との関係を求めた結果を Fig. 5 に示す。落下高さが増 加するとき, 衝撃ずり落ち量も比例して増加した。 また, 衝 撃吸収体を設置しない場合と比較すると, 設置した場合では 落下高さが同一であるときの衝撃ずり落ち量はほぼゼロに減 少した、脚部モデルが衝撃吸収体に達した瞬間から減速しな がら停止することによって, その運動エネルギが減少したた めと考える.すなわち, 衝撃吸収体の設置は衝撃力から生じ るずり落ち成分の除外に有効であった。

Fig. 6 は, 衝撃吸収体を設置した場合の脚部モデル落下高 さ（高さ条件 $=12$ 条件）と衝撃ずり落ち量との関係におけ る脚部モデル重量の影響を示す。衝撃力の大きさには脚部モ デルの重量が影響をおよぼすことから， 0.7， 0.8, 1.1 ならび に $1.5 \mathrm{kgf}$ のいずれの脚部モデル重量においても, 落下高さの 増加とともに衝撃ずり落ち量が増加した。特に, $0.7,0.8$ お よび $1.1 \mathrm{kgf} の$ 脚部モデル重量においては, 落下高さに対する 衝撃ずり落ち量がほぼ同一であった。しかしながら, 脚部モ デル重量が $1.5 \mathrm{kgf} の$ 条件においては, 他の 3 条件と比較し て衝撃ずり落ち量が大きく増加した。すなわち, 脚部モデル

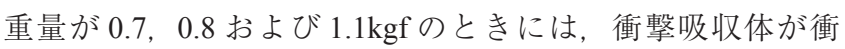
撃力を吸収できたために慣性力および抵抗力から生じるずり 落ち成分だけとなり, 脚部モデル重量に関係なく落下高さに 比例して衝撃ずり落ち量も増加した。また脚部モデル重量が $1.5 \mathrm{kgf}$ のきには, 衝撃吸収体が衝撃力を十分に吸収できな いために脚部モデル重量と落下高さの影響を受けて衝撃ずり

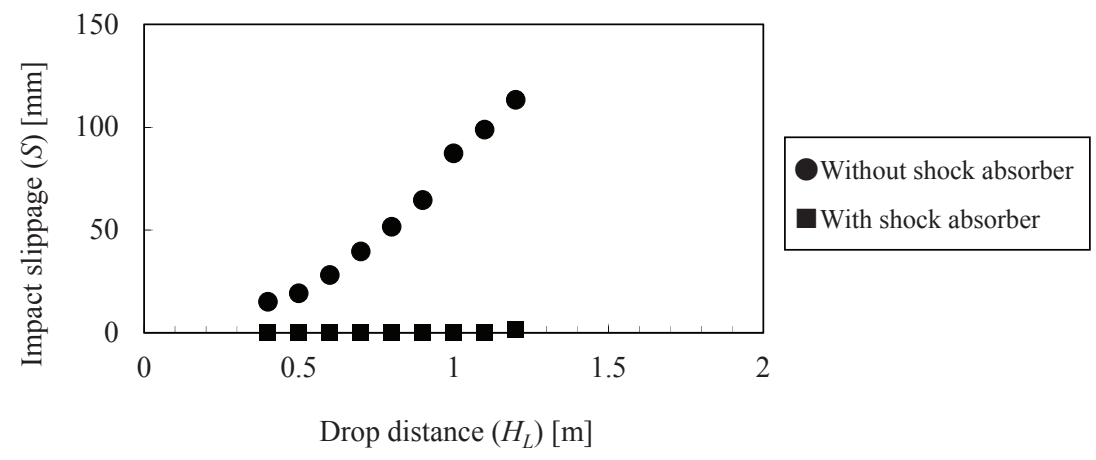

Fig. 5 Influence of shock absorber on relationship between impact slippage and drop distance. 


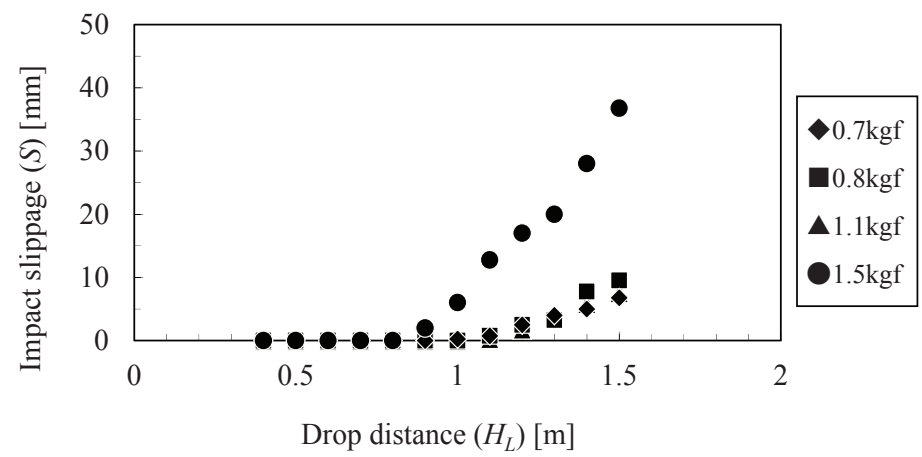

Fig. 6 Influence of weight of leg model on relationship between impact slippage and drop distance under using shock absorber.

落ち量が増加したものと考える。したがって, 脚部モデル重 量を軽くし， かつ衝撃吸収体を用いて衝撃力から生じるずり 落ち成分を十分に取り除くことによって，衝撃ずり落ち量を 効果的に計測・評価できると推察される.

\section{3 性能評価試験}

衣服圧と摩擦係数の異なる試料ソックスを用いて, 衝撃ず り落ち試験装置による性能評価試験を試みた。まず，ソック スロゴム部の平均衣服圧が異なる試料 $\mathrm{S} 1$ と試料 S3 を用い て, 衝撃吸収体を設置し, 落下高さを $1.0 \mathrm{~m}$, 脚部モデル重 量を $0.7 \mathrm{kgf}$ として評価試験を行い, 衝撃ずり落ち量を計測 した。な抄，平均衣服圧は，歪ゲージ型圧力センサ（共和電 業 PS5KC) 抒よび動歪計（共和電業 DPM-713B）を用い て，脚部モデルに試料ソックスを着装させた状態でのソック スロゴム部に扔ける正面, 背面, 左側面㧍よび右側面の合計 4 か所での圧力を測定し, その平均值を求めた。平均衣服圧 值を Table 1 に示す。評価試験の結果，平均衣服圧が $19 \mathrm{kPa}$ である試料 S3 の衝撃ずり落ち量は $0 \mathrm{~mm}$ であり, 平均衣服圧 が 7 $\mathrm{kPa}$ である試料 S1 の衝撃ずり落ち量は $293 \mathrm{~mm}$ であった。 評価試験の試作試験装置設定条件においては, 衝撃ずり落ち 量は慣性力および抵抗力から生じるずり落ち成分で成り立っ ており，衣服圧と衝撃ずり落ち量とは反比例の関係を示すと 考えられる。2 条件だけではあるが衣服圧と衝撃ずり落ち量 とは相反する結果となったことから，衣服圧が衝撃ずり落ち 量に及ぼ影響を評価できると推察される。

ついで, 試料 S3 について標準状態で調整した場合の衝撃 ずり落ち量と湿潤状態で調整した場合の衝撃ずり落ち量を計 測し, 摩擦係数の違いによる影響を比較した。なお湿潤状 態は, 試料ソックスを常温の水道水に 45 分間浸漬させた後, 手で軽く絞ったものである. 湿潤状態に扔ける脚部モデル上 での滑りやすさを事前に確認したところ，標準状態と比較し て非常に滑りやすかったことから，摩擦係数が小さくなって いることに加えて水分吸収による重量の増加が推測できる。 衝撃吸収体を設置し，落下高さを $1.0 \mathrm{~m}$, 脚部モデル重量を $0.7 \mathrm{kgf}$ で一定としたときの衝撃ずり落ち量は, 高い摩擦係数 の標準状態において $0 \mathrm{~mm}$, 低い摩擦係数の湿潤状態におい て 19mmであった，摩擦係数においても，衝撃ずり落ち量と
は相反する関倸にある. 2 条件だけではあるが摩擦係数と衝 撃ずり落ち量とは相反しており, 摩擦係数が衝撃ずり落ち量 に及ぼす影響を評価できると推察される。

したがって，試作した衝撃ずり落ち試験装置はスポーツ ソックスの衝撃ずり落ちを効果的に引き起こすことができる ことから，計測・評価として有用な試験方法である。なお， 試作衝撃ずり落ち試験装置に执いて, 脚部モデル重量を軽く, かつ衝撃吸収体を用いて脚部モデルの鉛直上向き運動を取り 除いて使用する場合には，力学モデルの解析が可能である.

\section{4. 結 言}

激しい運動時における衝撃ずり落ちを防止することによっ て, 脚部安全性や着衣快適性に優孔たスポーツソックスの開 発を目的として, 衝撃ずり落ち試験法について検討した結果 は,つぎのと扔りである。

（1）スポーツに扔けるソックスの衝撃ずり落ち現象は, 着装 脚部と地面との衝突によって生じるソックスに働く慣性 カ, ソックスと脚部との間の摩擦力, ならびに脚部に働 く衝撃力を用いた単純な力学モデルによって解析でき た。

（2）スポーツソックスを着装した円錐型脚部モデルを鉛直自 由落下させて, 衝撃ずり落ちを引き起こすための試験装 置を設計・開発し，その試駼法としての有用性を確かめ ることができた。

（3）競技中に抢ける不快な衝撃ずり落ちを防止し, 脚部の安 全性を確保するために必要な手段としては, 瀻維素材や 編組織，衣服圧，摩擦係数の調整・設定などをスポーツ ソックスの設計内容に加えることも重要である.

今後は, 被験者による着装ずり落ち試験と試作試験装置に よる衝撃ずり落ち試験との関倸性や, 衣服圧, 摩擦係数と衝 撃ずり落ち量との関倸性などについて詳細な検討が必要であ ろう。また，衝撃ずり落ちを防止した運動時の脚部安全性や 着衣快適性に優れた新規サッカーソックスの開発を目指した い. 


\section{謝 辞}

本研究の遂行ならびにまとめるに当たり懇切なるご指導と 貴重なご助言を賜りました信州大学繊維学部教授の松本陽一 先生ならびに同教授の諸岡英雄先生には蚸心より謝意を表し ます。

\section{References}

[1] JIS L 0215 (1984) "Glossary of Terms on Clothes"

[2] Matsuoka T, Nishimatsu T, Hananouchi T, Kamijo M, Toba E, Kondo M (2001) Sen'i Gakkaishi, 57, 334-337

[3] Kondo M, Takeuchi Y, Matsuzawa E, Yamaguchi M (2003) Proceedings of The $5^{\text {th }}$ Annual Conference of JSKE, 127
[4] Momota H, Makabe H, Mitsuno T, Ueda K (1993) J Jpn Res Assn Text End-Uses, 34, 603-614

[5] Tsujisaka T, Azuma Y, Matsumoto Y, Morooka H (2004) Text Res J, 74, 598-602

[6] Tsujisaka T, Matsumoto Y, Azuma Y, Morooka H (2005) J Text Mach Soc Japan (predecessor journal of J Text Eng), 58, T89-T94

[7] Tsujisaka T, Matsumoto Y, Ishizawa H, Azuma Y, Morooka H (2006) J Text Mach Soc Japan, 52, 1, 43-49

[8] Research Institute of Human Engineering for Quality Life (2011) “Japanese body size data book 2004-2006", p154, p162, p308, p312, HQL 